\title{
Prevention of disordered eating in adolescents: the role of perfectionism and media internalisation
}

\author{
Kelly Thompson ${ }^{1 *}$, Kavitha Dorairaj ${ }^{1}$, Simon Wilksch ${ }^{2}$, Tracey Wade ${ }^{2}$ Susan Paxton ${ }^{3}$, S Bryn Austin ${ }^{4,5}$, Sue Bryne ${ }^{1}$ \\ From 2013 ANZAED Conference: Inspiring Change: Person and Context \\ Melbourne, Australia. 23-24 August 2013
}

There is extensive research into eating disorder risk factors, and recently the focus has moved to investigating the mechanisms underlying these factors. The current study examines the interrelationships between eating disorder symptoms and two proposed risk factors: perfectionism and media internalisation. This study uses data collected as part of the Prevention Across the Spectrum randomized controlled trial, which involves approximately 2000 Grade 7 and 8 adolescents across Australia. Students were randomly allocated to one of three eating disorder prevention programs or a control group. Students were assessed in 4 waves (pre-intervention, post-intervention, 6-month follow-up and 12-month follow-up) and the assessment included measures of perfectionism (Frost Multidimensional Perfectionism Scale), media internalisation (Sociocultural Attitudes Towards Appearance Questionnaire), and shape and weight concerns (Eating Disorder Examination Questionnaire). Preliminary analyses using a sample of baseline data suggest that the relationship between perfectionism and eating disorder symptoms is mediated by media internalisation, with differential effects depending upon the dimension of perfectionism and the outcome measure used in the analysis. Part two of this study will investigate the effects of the intervention programs on this relationship and outcome. The findings presented will have implications for our understanding of the development and prevention of eating disorder symptomatology.

This abstract was presented in the Prevention stream of the 2013 ANZAED Conference.

\footnotetext{
* Correspondence: kellythompson@iprimus.com.au

${ }^{1}$ School of Psychology, The University of Western Australia, Australia
}

Full list of author information is available at the end of the article

\begin{abstract}
Authors' details
${ }^{1}$ School of Psychology, The University of Western Australia, Australia. ${ }^{2}$ School of Psychology, Flinders University, Australia. ${ }^{3}$ School of Psychological Science, LaTrobe University, Australia. ${ }^{4}$ Department of Social and Behavioral Sciences, Harvard School of Public Health, USA. ${ }^{5}$ Division of Adolescent and Young Adult Medicine, Boston Children's Hospital, USA.
\end{abstract}

Published: 14 November 2013

doi:10.1186/2050-2974-1-S1-O35

Cite this article as: Thompson et al:: Prevention of disordered eating in adolescents: the role of perfectionism and media internalisation. Journal of Eating Disorders 2013 1(Suppl 1):O35.

Submit your next manuscript to BioMed Central and take full advantage of:

- Convenient online submission

- Thorough peer review

- No space constraints or color figure charges

- Immediate publication on acceptance

- Inclusion in PubMed, CAS, Scopus and Google Scholar

- Research which is freely available for redistribution

Submit your manuscript at www.biomedcentral.com/submit
() Biomed Central 